\title{
On Attempts at Solvolytic Generation of Aryl Cations
}

\author{
L. R. Subramanian and Michael Hanack* \\ Institut für Organische Chemie, Universitat Tübingen, 74 Tübingen 1, Germany \\ Lawrence W. K. Chang, Michael A. Imhoff, and Paul v. R. Schleyer*1 \\ Department of Chemistry, Princeton University, Princeton, New Jersey 08540 \\ F. Effenberger* and W. Kurtz \\ Institut für Organische Chemie der Universitat Stuttgart, Stuttgart, Germany
}

Peter J. Stang* and Thomas E. Dueber

Chemistry Department, The University of Utah, Salt Lake City, Utah 84112

Received February 10, 1976

\begin{abstract}
The solvolysis of phenyl triflate (3), phenyl nonaflate (4), o-methylphenyl nonaflate (5), o-cyclopropylphenyl nonaflate (6), o-methoxyphenyl triflate (7), 2,6-dimethoxyphenyl triflate (8), 2,6-diisopropylphenyl triflate (9), 3,5dimethoxyphenyl triflate (10), 3,5-dicyclopropylphenyl triflate (11), 3,5-di(2-methylcyclopropyl)phenyl triflate (12), 2,4,6-tricyclopropylphenyl triflate (13), and 2,4,6-triisopropylphenyl triflate (14) were examined in great detail under a wide variety of conditions. In highly polar nonnucleophilic solvents no reaction was observed and the unreacted triflates were recovered quantitatively. In the presence of nucleophiles or nucleophilic solvents the sole products observed were the corresponding phenols. Careful labeling and product studies showed that these phenols arose by nucleophilic attack on sulfur and $\mathrm{S}-\mathrm{O}$ bond cleavage. We have not been able to find any evidence for aryl cation intermediates.
\end{abstract}

Contrary to earlier assumptions, the solvolyses of a number of vinyl substrates have been shown to proceed by ratelimiting heterolyses of their vinyl C-X bonds (eq 1), especially

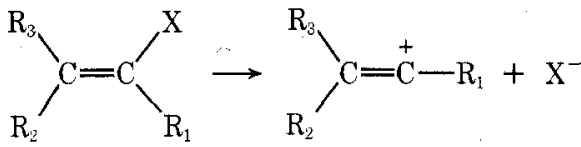

$$
\begin{aligned}
& 1 \\
& \mathrm{X}=\mathrm{Cl}, \mathrm{Br}, \mathrm{OSO}_{2} \mathrm{~F}, \mathrm{OSO}_{2} \mathrm{CF}_{3}, \mathrm{OSO}_{2} \mathrm{C}_{4} \mathrm{~F}_{9}
\end{aligned}
$$

when cation stabilizing substituents are present or a fluorosulfonate leaving group is employed. ${ }^{2}$ Rather than being elusive, vinyl cations 1 are now commonplace in organic chemistry.

Of the numerous species related ${ }^{2}$ to vinyl cations one of the most interesting is the phenyl (aryl) cation, 2. Despite con-<smiles>c1ccccc1</smiles>

siderable research, the existence of aryl cations as reactive intermediates long eluded firm proof. ${ }^{3}$ In the gas phase the phenyl cation is a high-energy species with $\Delta H_{\mathrm{f}}^{\circ}\left(298^{\circ} \mathrm{C}\right)=$ $270 \pm 4 \mathrm{kcal} / \mathrm{mol}$, ${ }^{4 a}$ which means that it is $11 \mathrm{kcal} / \mathrm{mol}$ less stable than the ethyl cation ${ }^{4 b}$ (Table I). Nevertheless, aryl cations have been postulated as intermediates in the thermal and photochemical decomposition of aryl diazonium salts. 5 However, dediazonization reactions can follow several pathways ${ }^{5 a, 6}$ involving possible biradical species, ${ }^{7}$ aryne intermediates, ${ }^{8}$ or one-step bimolecular mechanisms; ${ }^{9}$ the elucidation of precise reaction mechanisms and the exact nature of reactive intermediate(s) is complicated.

Recently, Swain and co-workers ${ }^{6}$ have shown that, in the absence of strong bases, reducing agents, or light, displacements on $\mathrm{C}_{6} \mathrm{H}_{5} \mathrm{~N}_{2}+$ in solution proceed by rate-determining formation of a singlet phenyl cation. Independent observations by Zollinger and co-workers ${ }^{10}$ on the reaction of molecular nitrogen under pressure with a phenyl cation adds sup- port to the existence of such species as reaction intermediates.

In order to study the possible solvolytic generation of aryl cations we investigated the preparation and reactions of a large number of aryl triflates and nonaflates.

\section{Results and Discussion}

The singlet phenyl cation, 2 , has a nominally vacant $\mathrm{sp}^{2}$ orbital orthogonal to the $\pi$ electrons of the benzene ring. Vacant orbitals of cations generally prefer to possess maximum $p$ character. This would require aryl cations, in analogy to vinyl cations, ${ }^{11}$ to have a linear geometry about the electrondeficient carbon. This electron-deficient carbon in a phenyl cation, however, due to symmetry, must be constrained to an unfavorable nonlinear geometry. ${ }^{12 \mathrm{~b}}$ Taft $^{\mathrm{i} 3}$ suggested that a triplet ion radical might be the structure of the aryl cation on the basis of aryldiazonium ion decomposition studies. In such a triplet ion radical, a $\pi$ electron from the benzene ring has entered the vacant $\mathrm{sp}^{2}$ orbital formerly occupied by the $\mathrm{C}-\mathrm{N}$ bonding electrons. Hence, one unpaired electron is in the $\pi$ system, delocalized as shown in $\mathbf{2 a}-\mathbf{d}$ (for the ${ }^{3} \mathrm{~B}_{1}$ state). An alternative triplet state $\left({ }^{3} \mathrm{~A}_{2}\right)$ is also possible, for which the resonance forms $\mathbf{2 a - d}$ do not provide a description of the $\pi$

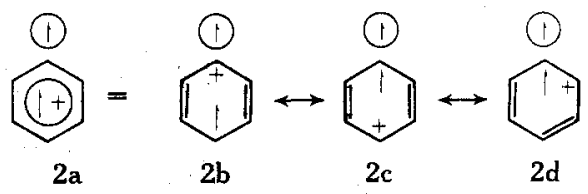

charge distribution; $a b$ initio calculations ${ }^{12}$ indicate this state to lie slightly higher in energy that the ${ }^{3} \mathrm{~B}_{1}$ one. Either of the triplet states can be strongly stabilized by resonance with $\pi$-donating substituents. ${ }^{12 \mathrm{c}}$

Theoretical calculations using the extended Hückel, ${ }^{14}$ INDO, ${ }^{6,15} \mathrm{CNDO} / \mathrm{S},{ }^{12 \mathrm{~d}}$ and most recently ab initio ${ }^{12 \mathrm{~b}, \mathrm{c}}$ levels predict the singlet phenyl cation to be the ground state with substantial delocalization of the positive charge throughout the molecule. The energy differences between the ${ }^{1} \mathrm{~A}_{1}$ singlet and the ${ }^{3} \mathrm{~B}_{1}$ and ${ }^{3} \mathrm{~A}_{2}$ triplet states have been variously calculated to be $20-150 \mathrm{kcal} / \mathrm{mol}$ in favor of the singlet state for the phenyl cation, ${ }^{6,12}$ but the energy separation strongly depends on substituents. ${ }^{12,15}$ Gleiter, Hoffmann, and Stohrer found ${ }^{14}$ 
Table I Relative Phenyl Cation Stabilization Energies

\begin{tabular}{|c|c|c|}
\hline Species & $\begin{array}{c}\Delta H_{\mathrm{f}}{ }^{\circ}, 25^{\circ} \mathrm{C}, \\
\text { gas phase }\end{array}$ & $\begin{array}{l}\text { Phenyl cation } \\
\text { stabilization } \\
\text { energies }\end{array}$ \\
\hline & 270 & \\
\hline $\begin{array}{l}\mathrm{C}_{2} \mathrm{H}_{3}{ }^{+} \\
\mathrm{C}_{2} \mathrm{H}_{5}{ }^{+} \\
\mathrm{CH}_{3} \mathrm{C}^{+}=\mathrm{CH}_{2} \\
\mathrm{CH}_{3}{ }^{+} \mathrm{CHCH}_{3}\end{array}$ & $\begin{array}{l}266 \\
219 \\
237 \\
192\end{array}$ & $\begin{array}{l}+3 \\
-11 \\
-18 \\
-33\end{array}$ \\
\hline
\end{tabular}

that electron-donating substituents in the meta position (relative to the carbon bearing the empty $\mathrm{sp}^{2}$ orbital) should stabilize the singlet electronic state by "through-bond" stabilization, ${ }^{14}$ although more recent calculations predict para substitution to be even more favorable. ${ }^{12}$ Possible credence is lent to the "through-bond" hypothesis by further theoretical calculations which show that the $\mathrm{C}-\mathrm{N}$ bond order is decreased in substituted phenyldiazonium ions by $\pi$-donor groups in the meta position and increased (or unchanged) by meta electron acceptors, in accord with thermal decomposition rates and quantum yields of substituted phenyldiazonium salts. ${ }^{15}$ Possible experimental evidence for the "through-bond" stabilization of aryl cations by meta $\pi$-donor substituents has been provided by Derocque et al. ${ }^{16}$ by mass spectral studies. Among a large number of aryl triflates investigated, 3,5di $(\alpha$-methylcyclopropyl)phenyl triflate (12) showed the largest percentage of direct formation of the corresponding aryl cation under electron impact, ${ }^{16}$ although the exact structural assignments of such species are never secure in the gas phase.

Guided by these theoretical considerations, ${ }^{17}$ we prepared the following aryl triflates and nonaflates, $3-14$, and investi-<smiles>CCOc1ccccc1</smiles><smiles>[N+]#[N+]c1ccccc1</smiles>

4<smiles>COc1ccccc1C</smiles>

5<smiles>[X]Oc1ccccc1C1CC1</smiles>

6<smiles>CCOc1ccccc1OC</smiles>

7<smiles>COc1cccc(OC)c1OC</smiles>

8<smiles>CCOc1c(C(C)C)cccc1C(C)(C)C</smiles>

9<smiles>CCOc1cc(C2(C)CC2)cc(C2(C)CC2)c1</smiles><smiles>CCOc1c(C(C)C)cc(C(C)C)cc1C(C)C</smiles>

14

$\mathrm{OTf}=\mathrm{OSO}_{2} \mathrm{CF}_{3}$

$$
\mathrm{ONf}=\mathrm{OSO}_{2} \mathrm{C}_{4} \mathrm{~F}_{9}
$$

gated their solvolytic behavior under a wide variety of conditions.

Compounds 3 and 4 were chosen as possible progenitors of the unsubstituted parent phenyl cation, compounds 5-9 were

Table II. Solvolysis of Phenyl Sulfonates 3 and 4

\begin{tabular}{|c|c|c|}
\hline Substrate & Rxn conditions & Product(s) \\
\hline 3 & $\mathrm{H}_{2} \mathrm{O}, 150^{\circ} \mathrm{C}, 14$ days & $\begin{array}{l}\text { No reaction } \\
3 \text { recovered }\end{array}$ \\
\hline 3 & $\begin{array}{c}\mathrm{CF}_{3} \mathrm{COOH}, \mathrm{CF}_{3} \mathrm{CO}_{2} \mathrm{Na}^{\prime} \\
150^{\circ} \mathrm{C}, 21 \text { days }\end{array}$ & $\begin{array}{l}\text { No reaction } \\
3 \text { recovered }\end{array}$ \\
\hline 3 & $\begin{array}{c}\mathrm{CH}_{3} \mathrm{COOH}, \mathrm{CH}_{3} \mathrm{CO}_{2} \mathrm{Na} \text {, } \\
150{ }^{\circ} \mathrm{C}, 21 \text { days }\end{array}$ & $\begin{array}{l}\text { No reaction } \\
3 \text { recovered }\end{array}$ \\
\hline 3 & $\begin{array}{l}\mathrm{CH}_{3} \mathrm{OH}, \mathrm{Et}_{3} \mathrm{~N}, 150^{\circ} \mathrm{C} \\
21 \text { days }\end{array}$ & $100 \%$ phenol \\
\hline 3 & $\begin{array}{l}50 \% \mathrm{EtOH}, \mathrm{Et}_{3} \mathrm{~N}, 150 \\
{ }^{\circ} \mathrm{C}, 21 \text { days }\end{array}$ & $100 \%$ phenol \\
\hline 3 & $\begin{array}{l}\mathrm{CF}_{3} \mathrm{CH}_{2} \mathrm{OH}, \mathrm{Et}_{3} \mathrm{~N}, 150 \\
{ }^{\circ} \mathrm{C}, 21 \text { days }\end{array}$ & $100 \%$ phenol \\
\hline 3 & $\begin{array}{c}98 \% \mathrm{CF}_{3} \mathrm{CH}_{2} \mathrm{OH}, \mathrm{Et}_{3} \mathrm{~N}, \\
150{ }^{\circ} \mathrm{C}, 21 \text { days }\end{array}$ & $100 \%$ phenol \\
\hline 3 & $\begin{array}{c}50 \% \mathrm{CF}_{3} \mathrm{CH}_{2} \mathrm{OH}, \mathrm{Et}_{3} \mathrm{~N}, \\
150^{\circ} \mathrm{C}, 21 \text { days }\end{array}$ & $100 \%$ phenol \\
\hline 3 & $\begin{array}{l}\mathrm{H}_{2} \mathrm{O}, \mathrm{NaOH}, 150^{\circ} \mathrm{C} \\
12 \text { hours }\end{array}$ & $100 \%$ phenol \\
\hline 4 & $\begin{array}{c}\mathrm{CF}_{3} \mathrm{COOH}, \mathrm{CF}_{3} \mathrm{CO}_{2} \mathrm{Na} \\
150^{\circ} \mathrm{C}, 21 \text { days }\end{array}$ & $\begin{array}{l}\text { No reaction } \\
4 \text { recovered }\end{array}$ \\
\hline 4 & $\begin{array}{l}50 \% \text { EtOH, } \mathrm{Et}_{3} \mathrm{~N}, 150 \\
{ }^{\circ} \mathrm{C}, 21 \text { days }\end{array}$ & $100 \%$ phenol \\
\hline
\end{tabular}

selected for possible classical inductive stabilization of aryl cations via electron-donating ortho substituents, and meta isomers 10-12 were selected to test the "through-bond" stabilization hypothesis of Gleiter and Hoffman. ${ }^{14,17}$ Cyclopropane substituents were selected for their efficacious stabilization of cations by "through-space" nonclassical overlap of orbitals ${ }^{18}$ and their demonstrated ability to stabilize vinyl cations. ${ }^{19}$ In addition aryl sulfonates 9 and 14 were chosen for possible relief of ground state steric crowding upon solvolysis and hence possible enhanced solvolytic reactivity.

The results of the solvolytic investigations are reported in Tables II-V. In buffered media at relatively high temperatures, arylsulfonate esters may undergo reaction via three possible mechanisms, illustrated in Scheme I for the parent

Scheme I. Mechanisms of Reaction of Arylsulfonate Esters $\mathrm{O}$

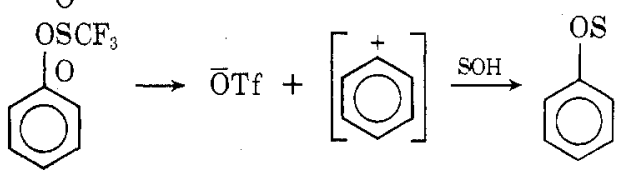

0

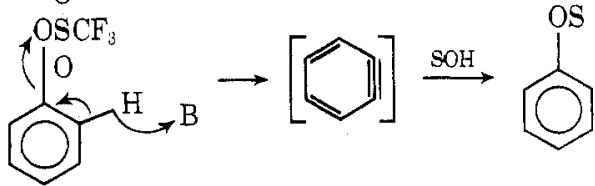

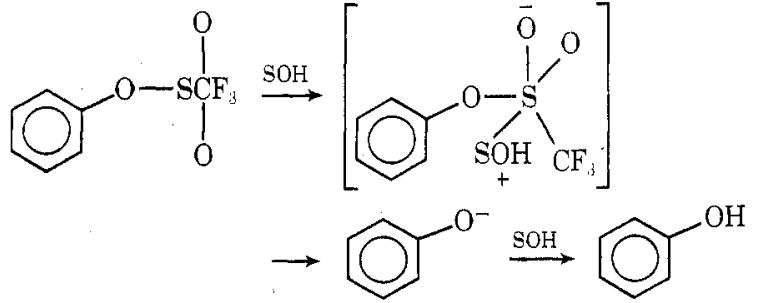

phenyl system. Reaction A involves aryl-oxygen cleavage, formation of the aryl cation, and subsequent capture by solvent. Path $B$ involves abstraction of a proton by a base (solvent or buffer), loss of triflate anion, and benzyne formation. This pathway would require the formation of a mixture of meta-and ortho-substituted products from an ortho-substituted arylsulfonate as well as the incorporation of deuterium into the ring in the presence of deuterated solvent. Mechanism $\mathrm{C}$ involves sulfur-oxygen cleavage via nucleophilic attack on sulfur resulting in the formation of phenol, rather than a 
Table III. Solvolysis of Ortho-Substituted Arylsulfonates

\begin{tabular}{|c|c|c|}
\hline Substrate & Rxn conditions & Product(s) \\
\hline 5 & & No reaction, 5 recovered \\
\hline 5 & $50 \%$ EtOH, $\mathrm{Et}_{3} \mathrm{~N}, 150^{\circ} \mathrm{C}, 21$ days & $o-\mathrm{CH}_{3} \mathrm{C}_{6} \mathrm{H}_{4} \mathrm{OH}(100 \%)$ \\
\hline 6 & & $o-\mathrm{C}_{3} \mathrm{H}_{5} \mathrm{C}_{6} \mathrm{H}_{4} \mathrm{OH}(50 \%), 6(50 \%)$ \\
\hline 6 & $50 \% \mathrm{EtOH}, \mathrm{Et}_{3} \mathrm{~N}, 150^{\circ} \mathrm{C}, 21$ days & $o-\mathrm{C}_{3} \mathrm{H}_{5} \mathrm{C}_{6} \mathrm{H}_{4}^{4} \mathrm{OH}(100 \%)$ \\
\hline 7 & $\mathrm{CH}_{3} \mathrm{OH}, 2,6$-lutidine, $125^{\circ} \mathrm{C}, 5$ days & $O-\mathrm{CH}_{3} \mathrm{OC}_{6} \mathrm{H}_{4} \mathrm{OH}(2 \%), 7(98 \%)$ \\
\hline 7 & $97 \% \mathrm{CF}_{3} \mathrm{CH}_{2} \mathrm{OH}, 2,6$-lutidine, $125^{\circ} \mathrm{C}, 20$ days & $o-\mathrm{CH}_{3} \mathrm{OC}_{6} \mathrm{H}_{4} \mathrm{OH}(7 \%), 7(93 \%)$ \\
\hline 7 & $60 \%$ EtOH, NaOAc, $180^{\circ} \mathrm{C}, 39 \mathrm{~h}$ & $0-\mathrm{CH}_{3} \mathrm{OC}_{6} \mathrm{H}_{4} \mathrm{OH}(83 \%), 7(17 \%)$ \\
\hline 8 & $60 \%$ EtOH, $\mathrm{NaOAc}, 180^{\circ} \mathrm{C}, 27 \mathrm{~h}$ & $2,6-\left(\mathrm{CH}_{3} \mathrm{O}\right)_{2} \mathrm{C}_{6} \mathrm{H}_{3} \mathrm{OH}(72 \%), 8(10 \%)$ \\
\hline 9 & $\mathrm{CH}_{3} \mathrm{OH}, \mathrm{NaOCH}_{3}, 150^{\circ} \mathrm{C}, 5 \mathrm{~h}$ & $2,6-(i-\mathrm{Pr})_{2} \mathrm{C}_{6} \mathrm{H}_{3} \mathrm{OH}(100 \%)$ \\
\hline 9 & $80 \%$ EtOH, $150^{\circ} \mathrm{C}, 10$ days & No reaction, 9 recovered \\
\hline 9 & $50 \%$ EtOH, $150^{\circ} \mathrm{C}, 10$ days & No reaction, 9 recovered \\
\hline 9 & $\mathrm{H}_{2} \mathrm{O}, 150^{\circ} \mathrm{C}, 10$ days & No reaction, 9 recovered \\
\hline $\mathbf{9}$ & $\mathrm{CH}_{3} \mathrm{COOH}, 150^{\circ} \mathrm{C}, 10$ days & No reaction, 9 recovered \\
\hline 9 & $50 \%$ EtOH, $\mathrm{NaOH}, 150^{\circ} \mathrm{C}, 5 \mathrm{~h}$ & $2,6-(i-\mathrm{Pr})_{2} \mathrm{C}_{6} \mathrm{H}_{3} \mathrm{OH}(100 \%)$ \\
\hline
\end{tabular}

Table IV. Solvolysis of Meta-Substituted Arylsulfonates

\begin{tabular}{|c|c|c|}
\hline Substrate & Rxn conditions & Product(s) \\
\hline 10 & $\mathrm{CH}_{3} \mathrm{OH}, 1,8$-bis $(N, N$-dimethyl $)$ naphthalene, $180^{\circ} \mathrm{C}, 20$ days & $3,5 \cdot\left(\mathrm{CH}_{3} \mathrm{O}\right)_{2} \mathrm{C}_{6} \mathrm{H}_{3} \mathrm{OH}(100 \%)$ \\
\hline 10 & $\mathrm{CF}_{3} \mathrm{CH}_{2} \mathrm{OH}, 1,8$-bis $(N, N$-dimethyl $)$ naph thalene, $125^{\circ} \mathrm{C}, 5$ days & 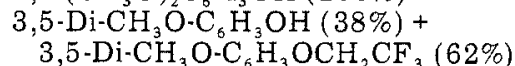 \\
\hline $\begin{array}{l}11 \\
12\end{array}$ & $\begin{array}{l}\mathrm{EtOH}-\mathrm{H}_{2}{ }^{18} \mathrm{O}, \mathrm{Et}_{3} \mathrm{~N}, 150^{\circ} \mathrm{C}, 21 \text { days } \\
\text { EtOH }-\mathrm{H}_{2}{ }^{18} \mathrm{O}, \mathrm{Et}_{3} \mathrm{~N}, 150^{\circ} \mathrm{C}, 21 \text { days }\end{array}$ & $\begin{array}{l}3,5 \text {-Dicyclopropyl } \mathrm{C}_{6} \mathrm{H}_{3} \mathrm{OH}(100 \%) \\
60 \% \text { phenol, } 40 \% 12\end{array}$ \\
\hline
\end{tabular}

Table V. Solvolysis of 2,4,6-Trisubstituted Arylsulfonates

\begin{tabular}{|c|c|c|}
\hline Substrate & Rxn conditions & Product(s) \\
\hline $\begin{array}{l}13 \\
14\end{array}$ & $\begin{array}{l}\mathrm{EtOH}-\mathrm{H}_{2}{ }^{18} \mathrm{O} \mathrm{Et}_{3} \mathrm{~N}, 150^{\circ} \mathrm{C}, 21 \text { days } \\
50 \% \mathrm{EtOH}, \mathrm{Et}_{3} \mathrm{~N}, 150^{\circ} \mathrm{C}, 21 \text { days }\end{array}$ & $\begin{array}{l}2,4,6-\left(c-\mathrm{C}_{3} \mathrm{H}_{5}\right)_{3} \mathrm{C}_{6} \mathrm{H}_{2} \mathrm{OH}(15 \%), 13(85 \%) \\
2,4,6-(i-\mathrm{Pr})_{3} \mathrm{C}_{6} \mathrm{H}_{2} \mathrm{OH}(<10 \%), 14(>90 \%)\end{array}$ \\
\hline
\end{tabular}

phenyl ether, when alcoholic solvents are employed. Such nucleophilic attack upon sulfur, and the attendant $\mathrm{S}-\mathrm{O}$ bond cleavage in the presence of bases, is a well-known phenomenon. ${ }^{20}$

Examination of the data in Table II reveals that the phenyl fluorosulfonate esters 3 and 4 do not lead to phenyl cation. Indeed they are totally inert even under extreme solvolytic conditions $\left(2-3\right.$ weeks at $150-180^{\circ} \mathrm{C}$ in polar, nonnucleophilic solvents). On the other hand, in nucleophilic solvents ${ }^{21}$ in the presence of amine buffers, quantitative phenol formation occurs. Solvolysis of 3 in EtOD- $\mathrm{D}_{2} \mathrm{O}$ under similar conditions also yielded phenol as the sole product. Mass spectral analysis of this phenol gave no indication $(<1 \%)$ of deuterium incorporation into the ring. This rules out the possibility of benzyne formation (path B) in this reaction. These results strongly implicate nucleophilic attack on sulfur and sulfur-oxygen bond cleavage ${ }^{20}$ as depicted in mechanism $\mathrm{C}$ in Scheme I.

Results in Table III reveal either no reaction or, under forcing conditions, sole formation of substituted phenols as products. In the case of ortho-substituted arylsulfonates only ortho-substituted phenols were observed with no detectable amount of meta isomers. In particular, 5 gave only $o$-cresol in $50 \% \mathrm{EtOH}$ as determined by GC analysis. Similarly, solvolysis of 6 in 50\% EtOH gave only o-cyclopropylphenol. This solvolysis product was methylated with diazomethane, and the methyl ether so obtained was found to be identical in all respects with an authentic sample prepared from pure $o$-cyclopropylphenol. Again, both a mechanism involving a benzyne or an aryl cation as possible intermediates are ruled out.

Solvolyses of 11,12 , and 13 were conducted in $\mathrm{EtOH}-\mathrm{H}, 2^{18} \mathrm{O}$ in order to check for ${ }^{18} \mathrm{O}$ incorporation in the phenolic products; however, careful mass spectral analysis revealed none, hence providing direct evidence for path $\mathrm{C}$ and $\mathrm{S}-\mathrm{O}$ cleavage rather than aryl-oxygen cleavage. The formation of the trifluoroethyl ether in the reaction of 10 in $\mathrm{CF}_{3} \mathrm{CH}_{2} \mathrm{OH}$ might, at first glance, indicate the intermediacy of an aryl cation.
However, control experiments demonstrated that the ether was formed subsequently from phenol and $\mathrm{CF}_{3} \mathrm{CH}_{2} \mathrm{OH}$. This is further substantiated by the reaction of ${ }^{18} \mathrm{O}$ (aryl-oxygen) labeled 10 in $\mathrm{CF}_{3} \mathrm{CH}_{2} \mathrm{OH}$. The 3,5-dimethoxyphenyl trifluoroethyl ether thus formed had retained all of the ${ }^{18} \mathrm{O}$ originally in the starting triflate. This rules out an aryl cation intermediate.

Finally, as the data in Table $\mathrm{V}$ as well as the results of substrate 9 indicate, even bulky substituents do not assist the solvolytic formation of aryl cations. The small yields of phenol formed in the reaction of 14 indicate that nucleophilic attack on sulfur and the subsequent S-O cleavage is sterically hindered.

Summary. It is evident from the foregoing results and discussion that although aryl cations may be intermediates in the reactions of certain aryldiazonium ions or may be observed in the gas phase $e^{4,16}$ they certainly do not form in the solvolyses of arylsulfonate esters even when "super" sulfonate leaving groups are employed. ${ }^{3}$ Instead of reaction via aryl cations, aryl triflates prefer to react via nucleophilic attack on sulfur and S-O cleavage. These experimental results further confirm the high energy and unstable nature of aryl cations. ${ }^{4,12}$ Moreover, because of the orthogonal arrangement of the vacant orbital at $\mathrm{C}$, and the filled $\pi$ orbitals of the ring, substituents are not very effective in providing significant stabilization of singlet aryl cations. ${ }^{12}$

\section{Experimental Section}

General. All boiling points and melting points are uncorrected. NMR, ir, and mass spectra were recorded on standard instruments as were GC determinations using the following columns: A, $3 \mathrm{ft} \times 0.25$ in. $20 \%$ Carbowax $20 \mathrm{M}$ on Chromosorb W; B, $5 \mathrm{ft} \times 0.25 \mathrm{in} .3 \% \mathrm{SE}-30$ on Chromosorb W; C, $3 \mathrm{ft} \times 0.125$ in. $5 \%$ FFAP on Chromosorb W; D, $3 \mathrm{ft} \times 0.125$ in. $10 \%$ Carbowax $20 \mathrm{M}$ on Chromosorb W; E, $5 \mathrm{ft} \times 0.125$ in. $5 \%$ FFAP on Chromosorb W; F, $5 \mathrm{ft} \times 0.125$ in. $5 \% \mathrm{SE}-30$ on Chromosorb W; G, $9 \mathrm{ft} \times 0.25 \mathrm{in}$. $15 \%$ silicon oil DC 200 on Chromosorb $\mathrm{P}$.

Reagents. Trifluoromethanesulfonic acid (triflic acid) was pur- 
Table VI. Physical and Spectral Properties of Arylsulfonate Esters ${ }^{a}$

\begin{tabular}{ccll}
\hline Compd & $\mathrm{Bp},{ }^{\circ} \mathrm{C}(\mathrm{mm})$ & \multicolumn{1}{c}{$\mathrm{Ir} a$} & \multicolumn{1}{c}{ NMR $b, c$} \\
\hline 3 & $67-68(15)$ & $1430,1255,1220,1140$ & $7.0-7.3(\mathrm{~m}, 5 \mathrm{H})$ \\
6 & $140-145(15)$ & $1440,1250,1210,1155$ & $0.5-1.3(\mathrm{~m}, 4 \mathrm{H}) 1.9-2.4(\mathrm{~m}, 1 \mathrm{H})$ \\
& & & $7.0-7.45(\mathrm{~m}, 4 \mathrm{H})$ \\
7 & & $1435,1245,1210,1145$ & $3.9(3 \mathrm{H}), 6.9-7.5(\mathrm{~m}, 4 \mathrm{H})$ \\
8 & & $1430,1250,1215,1145$ & $3.8(\mathrm{~s}, 6 \mathrm{H}), 6.4-7.3(\mathrm{~m}, 3 \mathrm{H})$ \\
& & $1385,1205,1130$ & $1.12(\mathrm{~d}, 12 \mathrm{H}, \mathrm{J}=5.9 \mathrm{~Hz})$ \\
10 & & & $3.25(\mathrm{septet}, 2 \mathrm{H}), 7.08(\mathrm{~s}, 3 \mathrm{H})$ \\
13 & $110-115(12-15)$ & $1430,1250,1215,1150$ & $3.8(\mathrm{~s}, 6 \mathrm{H}), 6.4(\mathrm{~m}, 3 \mathrm{H})$ \\
& & & $0.45-1.15(\mathrm{~m}, 12 \mathrm{H}), 1.79(\mathrm{~m}, 1 \mathrm{H})$ \\
14 & \multirow{2}{*}{$(0.05)$} & & $2.08(\mathrm{~m}, 2 \mathrm{H}), 6.47(\mathrm{~s}, 2 \mathrm{H})$ \\
& & & $1.24(\mathrm{~d}, 12 \mathrm{H}), 1.26(\mathrm{~d}, 6 \mathrm{H})$ \\
& & & $2.90(\mathrm{septet}, 1 \mathrm{H}), 3.33(\mathrm{septet}, 2 \mathrm{H})$
\end{tabular}

$a$ Satisfactory elemental $\mathrm{C}$ and $\mathrm{H}$ analyses were obtained for all new compounds. $b$ Neat film. $c$ Parts per million downfield; TMS, 0.0 .

chased from the $3 \mathrm{M} \mathrm{Co}$. and converted to its anhydride with $\mathrm{P}_{2} \mathrm{O}_{5}, 2.2$ Nonafluorobutanesulfonyl fluoride was kindly supplied by Farbenfabriken Bayer. Proton Sponge, 1,8-bis(dimethylamino)naphthalene and 2,6-lutidine were purchased from Aldrich Chemical Co. Oxygen-18 enriched $\mathrm{H}_{2} \mathrm{O}$ containing 1.75 atom $\%{ }^{18} \mathrm{O}$ was purchased from BioRad and the one containing 25 atom $\%{ }^{18} \mathrm{O}$ from Firma Roth, West Germany, and diluted to 12.5 atom $\%{ }^{18} 0$. o-Methoxyphenol, 2,6dimethoxyphenol, 3,5-dimethoxyphenol, and 2,6-diisopropylphenol were purchased from Aldrich Chemical Co. o-Cyclopropylphenol was kindly provided by Dr. P. Cagniant, University of Metz, France 3,5-dicyclopropylphenol, 2,4,6-tricyclopropylphenol, 2,4,6-triisopropylphenol, and 3,5-(2-methylcyclopropyl)phenol were prepared according to Effenberger et al. ${ }^{23}$

Aryl triflates were prepared by a procedure similar to the preparation of alkyl tosylates ${ }^{24}$ by addition of an equivalent amount of triflic anhydride to a pyridine phenol mixture of $0^{\circ} \mathrm{C}$. In most instances pyridine triflate precipitated from the reaction mixture during a 24-h period while the mixture was kept in a refrigerator. The reaction mixture was poured into ether and washed several times with water the ether solution was dried over $\mathrm{MgSO}_{4}$, and the solvent evaporated. The crude aryl triflates were purified first by column chromatography on silica gel and then by preparative GC

Aryl nonaflates were prepared similarly, as previously reported ${ }^{25}$ using triethylamine as the base. Physical and spectral properties of previously unknown aryl triflates and nonaflates are reported in Table VI; for 4 and 5 see ref 18 and for 11 and 12 see ref 23 .

Solvolysis and Product Identification. Solvolyses of sulfonate esters 3-14 were carried out on a 10-mmol scale or less under the conditions given in Tables II-V in thick-walled glass ampules. Analysis was by means of either direct injection into the GC and use of authentic samples or by workup as follows. Most of the solvent was removed by aspirator and the residue dissolved in ether. The ether layer was washed with $5 \% \mathrm{NaOH}(4 \times 20 \mathrm{ml})$ and the phenol regenerated by acidification with ice-cold dilute $\mathrm{HCl}$ and extracted with ether, and identified with the aid of authentic samples. The $\mathrm{NaOH}$ insoluble portion was separately worked up by washing the ether layer from which the phenol was extracted, with ether, drying over $\mathrm{Na}_{2} \mathrm{SO}_{4}$, and removing the solvent. In all instances no or only negligible amounts of residue was observed.

The 3,5-dimethoxyphenyl trifluoroethyl ether from the reaction of 10 in $\mathrm{CF}_{3} \mathrm{CH}_{2} \mathrm{OH}$ was identified by spectral means as follows: mass spectrum $m / e 236\left(\mathrm{M}^{+}\right)$; ir $\left(\mathrm{CCl}_{4}\right) 1250,1160 \mathrm{~cm}^{-1}$; NMR $\left(\mathrm{CCl}_{4}\right) \delta 3.75$ $\left(6 \mathrm{H}, \mathrm{OCH}_{3}\right), 4.3\left(2 \mathrm{H}, \mathrm{q}, \mathrm{OCH}_{2} \mathrm{CF}_{3}\right), 6.1(\mathrm{~m}, 3 \mathrm{H})$.

Anal. Calcd: C, 50.84; H, 4.70. Found: C, 50.69; H, 4.75 .

Preparation of 3,5-Di- $\mathrm{CH}_{3} \mathrm{OC}_{6} \mathrm{H}_{3}{ }^{18} \mathrm{OH}$. Three grams $(0.02 \mathrm{~mol})$ of 3,5-dimethoxyaniline was mixed with $11 \mathrm{ml}$ of $6 \mathrm{~N}$ sulfuric acid. The slurry was cooled to $0^{\circ} \mathrm{C}$. in an ice-salt bath and stirred. Then $4 \mathrm{ml}$ of $5 \mathrm{~N}$ sodium nitrite solution was added dropwise at a rate which kept the temperature of the reaction mixture between 0 and $5^{\circ} \mathrm{C}$. After addition was completed, the mixture was stirred at $0^{\circ} \mathrm{C}$ for $20 \mathrm{~min}$ and filtered through glass filter. The filtrate was kept in ice-salt bath for $15 \mathrm{~min}$. When forming the diazonium salt, $4 \mathrm{ml}$ of concentrated sulfuic acid was added to $100 \mathrm{ml}$ of ${ }^{18} \mathrm{O}$-enriched water. The solution was divided equally in to two flasks and heated to boiling. The liquid from diazotization was added to the refluxing acidified ${ }^{18} \mathrm{O}$-enriched water at such a rate that the mixture boiled very vigorously. After addition was completed, the reaction mixture was refluxed for $5 \mathrm{~min}$ and cooled to room temperature. The two portions of the reaction mixture were combined and extracted with ether. The ethereal so- lution was then dried $\left(\mathrm{MgSO}_{4}\right)$ and evaporated. The crude product was purified by silica gel column chromatography to give $350 \mathrm{mg}$ of phenol. Mass spectrometric analysis indicated an ${ }^{18} \mathrm{O}$ content for phenol of 1.55 atom $\%$. The ${ }^{18} \mathrm{O}$ content of the ether generated by solvolysis of the labeled triflate in $\mathrm{CF}_{3} \mathrm{CH}_{2} \mathrm{OH}$ was analyzed by $\mathrm{GC} /$ mass spectrum. The results from two demonstrations indicate an ${ }^{18} \mathrm{O}$ content for the product ether of $1.6 \pm 0.3$ atom $\%{ }^{18} \mathrm{O}$.

Acknowledgments. We thank Dr. Jonas of Farben Fabrik Bayer at Leverkusen for the sample of nonafluorobutanesulfonyl fluoride and Dr. Cagniant of the University of Metz, France, for a sample of 0 -cyclopropylphenol. This work was supported by the Deutsche Forschungsgemeinschaft in Germany, the Research Corporation in Utah, and the National Science Foundation (GP-29078X) at Princeton.

Registry No.-3, 17763-67-6; 4, 25628-11-9; 5, 42096-33-3; 6, $60319-06-4 ; 7,59099-58-0 ; 8,60319-07-5 ; 9,60319-08-6 ; 10,60319-09-7$ 11, 41381-28-6; 12, 41381-29-7; 13, 60319-10-0; 14, 60319-11-1; phenol, 108-95-2; o-methoxyphenol, 90-05-1; 2,6-dimethoxyphenol, 91-10-1; 2,6-diisopropylphenol, 2078-54-8; 3,5-dimethoxyphenol, 500-99-2; 3,5-dicyclopropylphenol, 41381-26-4; bis(1-methylcyclopropyl)phenol, 41381-27-5; 2,4,6-tricyclopropylphenol, 60319-12-2; 2,4,6triisopropylphenol, 2934-07-8; triflic anhydride, 358-23-6; 3,5-dimethoxyphenyl trifluoroethyl ether, 60319-13-3.

\section{Reference and Notes}

(1) Institute of Organic Chemistry, University of Erlangen-Nürnberg, $8520 \mathrm{Er}$ langen, West Germany

(2) For reviews see L. R. Subramanian and M. Hanack, J. Chem. Educ., 52 80 (1975); P. J. Stang, Prog. Phys. Org. Chem., 10, 205 (1973); G. Modena and U. Tonellato, Adv. Phys. Org. Chem., 9, 185 (1971); M. Hanack, Acc. Chem. Res., 3, 209 (1970); H. G. Richey, Jr., and J. M. Richey, "Carbonium Ions", Vol. II, G. A. Olah and P. v. R. Schleyer, Ed., Interscience, New York, N.Y., 1970.

(3) (a) T. M. Su, W. F. Sliwinski, and P. v. R. Schleyer, J. Am. Chem. Soc., 91, 5386 (1969); (b) L. R. Subramanian and M. Hanack, Chem. Ber, 105, 1465 5386 (1969); (b) L. R. Subramanian and M. Hanack, Cherm. Ber., 105, 1465
(1972); (c) A. Streitwieser, Jr., and A. Dafforn, Tetrahedron Lett., 1435 (1976)

(4) (a) J. L. Beauchamp, Adv. Mass. Spectrom., 6, 717 (1974); (b) J. L. Franklin, J. G. Dillard, H. M. Rosenstock, J. T. Herron, K. Draxl, and F. H. Field "Ionization Potentials, Appearance Potentials and Heats of Formation of Gaseous Positive lons"', U.S. Department of Commerce, National Bureau of Standards, NSRDS-NBS 26, 1969

(5) (a) H. Zollinger, Acc. Chem. Res., 6, 335 (1973); (b) J. Miller, "Aromatic Nucleophilic Substitution". Elsevier, Amsterdam, 1968; (c) R. W. Alder, Nucleophilic Substitution", Elsevier, Amsterdam, 1968; (c) R. W. Alder, R. Baker, and J. M. Brown, "Mechanis

(6) C. G. Swain, J. E. Sheats, and K. G. Harbison, J. Am. Chem. Soc., 97, 783 $791,796(1975)$.

(7) N. Kamigata, M. Kobayashi, and H. Minto, Bulf. Chem. Soc. Jpn., 45, 2047 (1972); R. A. Abramovitch and F. F. Gadallah, J. Chem. Soc., B, 497 (1968).

(8) J. G Cadogan, Acc. Chem Res, 4, 186 (1971)

(9) E. S. Lewis et al., J. Am. Chem. Soc., 91, 419,426, 430 (1969); R. A Abramovitch and J. G. Saha, Tetrahedron, 21, 3297 (1965).

(10) R. G. Bergstrom, G. H. Wahl, Jr., and H. Zollinger, Tetrahedron Lett., 2975 (1974).

11) (a) W. D. Pfeifer, C. A. Bahn, P. v. R. Schleyer, S. Bocher, C. E. Harding K. Hummel, M. Hanack, and P. J. Stang, J. Am. Chem. Soc., 93, 1513 (1971); (b) E. Lamparter and M. Hanack, Chem. Ber, 105, 3789 (1972) (c) R. J. Hargrove and P. J. Stang, Tetrahedron, 32, 37 (1976).

(12) (a) J. D. Ditl, P. v. R. Schleyer, and J. A. Pople, Tetrahedron Lett., 2857 (1975); (b) J. D. Dill, P. v. R. Schleyer, J. A. Pople, and E. Haselbach, J. Am. 
Chem. Soc., in press; (c) J. D. Dill, P. v. R. Schleyer, and J. A. Pople, ibid. in press; (d) H. H. Jaffe and G. F. Koser, J. Org. Chem., 40, 3082 (1975).

(13) R. W. Taft, J. Am. Chem. Soc., 83, 3350 (1961)

(14) R. Gleiter, RHoffmann, and W. D. Stohrer, Chem. Ber., 105, 8 (1972)

(15) R. J. Cox, P. Bushnell, and E. M. Evleth. Tetrahedron Lett., 207 (1970); E. M. Evleth and P. M. Horowitz, J. Am. Chem. Soc., 93, 5636 (1971).

(16) J. L. Derocque, F. Effenberger, and W. Kurtz, submitted for publication.

(17) Many of the compounds chosen for study were based on the work of Gleiter Hoffmann, and Stohrer, ${ }^{14}$ which dealt principally with "through-bond ef fects'. Subsequent ab initio calculations ${ }^{12}$ on a wider range of substituents revealed, however, that through-bond effects are relatively minor in importance. However, the compounds reported in the present paper are representative. The ab initio calculations indicate that the greatest stabilization of singlet forms to be expected is from a planar $\rho-\mathrm{NH}_{2}$ group but the magnitude of the stabilization is relatively small and should not be enough to overcome the inherent instability of a singlet phenyl cation.
(18) M. Hanack and H. J. Schneider, Angew. Chem., 79, 709 (1967); J. Haywood Farmer, Chem. Rev., 74, 315 (1974).

(19) M. Hanack, T. Bassler, W. Eymann, W. E. Heyd, and R. Kopp, J. Am. Chem Soc., 96, 6686 (1974)

(20) C. A. Bunton and Y. F. Frei, J. Chem. Soc., 1872 (1951); S. Oae, T. Fukumoto, and R. Kiritani, Bull. Chem. Soc. Jpn., 36, 346 (1963); S. Oae and R. Kiritani, ibid., 38, 765 (1965); R. H. Summerville, C. A. Senkler, P. v.
R. Schleyer, T. E. Dueber, and P. J. Stang, J. Am. Chem. Soc, 96, 1100 R. Schleyer, T. E. Dueber, and P. J. Stang, J. Am. Chem. Soc, 96, 1100
(1974).

(21) P. E. Peterson and F. J. Waller, J. Am. Chem. Soc., 94, 991 (1972); T. W. Bentley, F. L. Schadt, and P. v. R. Schleyer, ibid, 94, 992 (1972).

(22) T. Burdon, I. Farazmand, M. Stacey, and J. C. Tatlow, J. Chem. Soc., 2574 (1957); P. J. Stang and T. E. Dueber, Org. Synth., 54, 79 (1974)

(23) W. Kurtz, P. Fischer, and F. Effenberger, Chem. Ber. 106, 525 (1973).

(24) L. F. Fieser and M. Fieser, "Reagents for Organic Synthesis", Vol. I, Wiley, New York, N.Y., 1967.

(25) L. R. Subramanian, H. Bentz, and M. Hanack, Synthesis, 293 (1973) 